\title{
Culture And Community Partnership Approach to Making a Healthy Indonesian Society (GERMAS) With The Helix Method
}

\author{
Angga Irawan¹, Ahmad Hidayat ${ }^{2}$, Jami Hariyadi ${ }^{3}$ \\ 1,2,3 University of Sari Mulia, Indonesia
}

\section{Article Info}

Article History:
Submit Dec 5th, 2020
Accepted Dec 12th, 2020
Published Dec 30th 2020
Keywords:
Healthy Living; Community
Movement (Germas);
Partnership

\section{INTRODUCTION}

GERMAS is a movement with the aim of improving people's healthy life and leaving unhealthy habits and behavior of society. ${ }^{1}$ One of the areas that become national priorities based on the Decree of the
GERMAS is a movement with the aim of improving people's healthy life and leaving unhealthy habits and behavior of society. One of the areas that become national priorities based on the Decree of the Minister of Villages for Disadvantaged Areas and Trans-Migration of the Republic of Indonesia Number 126 of 2017 concerning the determination of priority villages for village development targets, development of underdeveloped areas and transmigration, including the Village Assistance of Banjar Regency, South Kalimantan Problems in the health sector in Banjar Regency can be seen from the Health Profile Data for Banjar Regency in 2017 which shows the incidence of infectious and non-communicable diseases that are still experienced by many people in Banjar Regency such as ISPA, Hypertension, Rheumatism, Gastritis, Duodenitis, Diarrhea, Dermatitis and Pulmonary TB. One of the concepts that can be used in the implementation of the GERMAS action program is the concept of a partnership with an approach to religious figures, educational institutions, society, and the media. This study uses a quantitative descriptive-analytical design with a quantitative descriptive survey method with a random sampling technique. By using the instrument used in this study is a questionnaire sheet. Based on the research results obtained as follows: knowledge level as much as $53 \%$, physical activity $70 \%$, eating fruit and vegetable foods $75 \%$, alcohol consumption $56 \%$, health checks $15 \%$, environmental hygiene $45 \%$, using a latrine $23 \%$, use of media as much as $80 \%$ and social activities as much as $80 \%$. The results of this study hope that the people of Desa Pembantanan will implement a community movement for healthy living which includes 4 indicators, namely increasing knowledge, not drinking alcohol, environmental hygiene, and not using latrines, so that they can avoid health problems from noncommunicable diseases.
Minister of Villages for Disadvantaged Areas and Trans-Migration of the Republic of Indonesia Number 126 of 2017 concerning the determination of priority villages for village development targets, development of underdeveloped areas and transmigration, including the Village

Corresponding author:

Angga Irawan

angga_irawan10@yahoo.co.id

South East Asia Nursing Research, Vol 2 No 4, December 2020

ISSN:2685-032X

DOI: $\underline{\text { https://doi.org/10.26714/seanr.2.4.2020.8-19 }}$ 
Assistance of Banjar Regency, South Kalimantan.2,3 Problems in the health sector in Banjar Regency can be seen from the Health Profile Data for Banjar Regency in 2017 which shows the incidence of infectious and non-communicable diseases that are still experienced by many people in Banjar Regency such as ISPA, Hypertension, Rheumatism, Gastritis, Duodenitis, Diarrhea, Dermatitis and Pulmonary TB. ${ }^{3}$

One of the concepts that can be used in the implementation of the GERMAS action program is the concept of a partnership with an approach to Religious Figures, Educational Institutions, Communities, and Media, which are expected to collaborate and synergize in community activities in the GERMAS program. ${ }^{4-7}$ The GERMAS program through partnerships will consider aspects of local culture. ${ }^{8}$ This is intended to be well accepted by the target community, so that this action becomes a behavior that is inherent in everyday life. In the interests of disseminating the program in order to create an image of the program among the target audience, cooperation between the media, educational institutions, community leaders, health services and community leaders is required. ${ }^{9}$

Pembatanan Village is one of the underdeveloped villages in the Sungai Tabuk Subdistrict, Banjar Regency which is the National priority area based on the decision to describe the villages of disadvantaged areas and transmigration of the Republic of Indonesia Number 126 of 2017. Regarding the determination of priority villages for village development targets, development of disadvantaged areas. Problems in the health sector in Banjar Regency can be seen in the 2018 Banjar District Health Profile which shows that health problems are a priority in reducing the Sustainable Development Goal (SGDs) target. ${ }^{10}$ In addition, the prevalence of tuberculosis, hypertension, asthma and dermatitis experienced by the people of Pembantanan Village is in the area of Sungai
Tabuk District which is a village on the banks of the river.

Meanwhile, the total population of the Assistance Village is 3,345, 1,746 male and 1,599 female in the district. Sungai Tabuk, Banjar Regency, South Kalimantan 70653. Based on the existing resources in the village of Pembantan, as follows: health workers, farmers, craftsmen, construction workers and carpenters. There are public service facilities in the assistance village such as health services ( 2 puskesmas and 1pustu), education centers (PAUD $=1, \mathrm{TK}=$ $3, \mathrm{SD}=2$, Islamic boarding schools $=3$, Madrasah TS $=2$, Madrasah Itthadiyah $=3$, Madrasyah Aliyah $=1$ ). In addition, there is a village fund to develop BUMDES (bumdes which has already run kelotok rental and sale of farm products). The community in the Assistance Village area is a heterogeneous community that is more receptive to change and has an impact on population dynamics from the center of community activities around it. The form of activities in the assistance village area consists of 2 activities, namely: 1) government: Government programs such as PNPM and PAMSIMAS while; 2) community self-help activities consisting of youth activities, recitation, and posyandu

Meanwhile, the Village Infrastructure Infrastructure is still very limited, such as: (suspension bridges, with wing ropes that are about to break and wooden bridges with many holes), which are the main connecting roads between villages and the transKalimantan road axis. The facilities in the village area include: health services consisting of 2 health centers and 1 pustu, education centers consisting of PAUD $=1$, $\mathrm{TK}=3, \mathrm{SD}=2$, Islamic boarding schools $=3$, Madrasah TS $=2$, Madrasah Itthadiyah $=3$, Madrasyah Aliyah $=1$, badminton court and hall. While developments in the assistance village area are such as the office of the village head, while the organizations come from the community such as Pustu and Posyandu, while there are several party organizations. government such as PNPM 
and PAMSIMAS meanwhile; 2) community self-help activities consisting of youth activities, recitation, and posyandu

Meanwhile, the Village Infrastructure Infrastructure is still very limited, such as: (suspension bridges, with wing ropes that are about to break and wooden bridges with many holes), which are the main connecting roads between villages and the transKalimantan road axis. The facilities in the village area include: health services consisting of 2 health centers and 1 pustu, education centers consisting of PAUD $=1$, $\mathrm{TK}=3, \mathrm{SD}=2$, Islamic boarding schools $=3$, Madrasah TS $=2$, Madrasah Itthadiyah $=3$, Madrasyah Aliyah $=1$, badminton court and hall. While developments in the assistance village area are such as the office of the village head, while the organizations come from the community such as Pustu and Posyandu, while there are several party organizations.

The purpose of this study is to determine the factors that influence society in the Healthy Indonesian Society Movement.

\section{METHODS}

This research is a quantitative research with a descriptive research design. The research approach used was cross sectional. This study examines the factors that influence the community in the Healthy Indonesian Community Movement in the Village of Assistance.

Respondents of this study were members of the village community in South Kalimantan. respondents totaled 80 people according to the inclusion and exclusion criteria. The sampling technique used was simple random sampling.

Research variables have been measured using a questionnaire. The questionnaire used has been declared valid and reliable based on the results of the validity test and reliability test.
Researchers have provided explanations to potential respondents before the researchers conducted data collection. The explanation that has been done includes the objectives of the research, the benefits of the research and the consequences that must be borne in the research. After giving an explanation to the respondent, the researcher asked the respondent to sign the informed consent sheet. the researcher did not include the identity of the respondent in the research results.

\section{RESULTS}

The results of this study describe the results of research on the description of the Partnership with the Healthy Living Community Movement with the Penta Helix Approach. Data collection was carried out in August from 5 to 9 October 2020, with a total of 80 respondents. The number of clients who dropped out during the research process did not exist, because the researcher did this by directly visiting clients, so that the total results of this study were 80 respondents. This research was conducted in the village of Banjar Regency.

\section{Description of the Characteristics of Respondents in the Healthy Living Community Movement in the Assistance Village area.}

The results of the study show that the gender of the most respondents is male, namely 56 people $(70 \%)$ while $24(30 \%)$ women. The description of the education level of the most respondents is high school graduation, namely 27 (36.2\%) while the lowest is college graduated 9 respondents (11.2\%). The most respondents' education level is income, namely 41 (26\%) while the lowest is 39 respondents (48.8\%). The job description of the most respondents is income, namely 30 (37.5\%) while the lowest is 6 respondents $(7.5 \%)$. 
Description of Factors Affecting Society in Healthy Indonesian Community Movement in Assistance Villages.

Table 1

Distribution of Respondents Characteristics in Assistance Villages $2020(\mathrm{n}=80)$

\begin{tabular}{|c|c|c|}
\hline Indicators & $\mathrm{f}$ & $\%$ \\
\hline \multicolumn{3}{|l|}{ Knowledge } \\
\hline Knowing & 53 & 66.2 \\
\hline Don't know & 27 & 33.8 \\
\hline \multicolumn{3}{|l|}{ Physical Activity } \\
\hline Knowing & 70 & 87.5 \\
\hline Don't know & 10 & 12.5 \\
\hline \multicolumn{3}{|c|}{ Fruit and Vegetable Diet } \\
\hline Knowing & 75 & 93.8 \\
\hline Don't know & 5 & 6.2 \\
\hline \multicolumn{3}{|l|}{ Smoking Behavior } \\
\hline Smoke & 73 & 91.2 \\
\hline Do not smoke & 7 & 8.8 \\
\hline \multicolumn{3}{|c|}{ Consuming Alcoholic Drinks } \\
\hline Not Consuming & 24 & 30 \\
\hline Consume & 56 & 70 \\
\hline \multicolumn{3}{|c|}{ Consuming Drinks, Health } \\
\hline To do & 15 & 18.8 \\
\hline Do not do & 65 & 81.2 \\
\hline \multicolumn{3}{|c|}{ Environmental Cleanliness } \\
\hline Done & 45 & 56.2 \\
\hline Is not done & 35 & 43.8 \\
\hline \multicolumn{3}{|l|}{ using latrines } \\
\hline Done & 23 & 28.8 \\
\hline Is not done & 57 & 71.2 \\
\hline \multicolumn{3}{|c|}{ Maintaining Environmental Cleanliness } \\
\hline Done & 80 & 100 \\
\hline Is not done & 0 & 0 \\
\hline \multicolumn{3}{|c|}{ Social Support and Community Leaders } \\
\hline Get social & 80 & 100 \\
\hline
\end{tabular}

The results of the study show that the knowledge of germas knowing is 53 people (66.2\%), 27 people do not know (33.8\%). The description of physical activity carried out by respondents is 70 people $(87.5 \%)$, not done by 10 people (12.5\%). Most of it was done, namely 75 people $(93.8 \%)$, not 5 people (6.2\%). Most of the people smoked, namely 73 people $(91.2 \%), 7$ people $(8.8 \%)$ did not smoke. The pattern of consuming alcoholic drinks is 56 people (70\%), not consuming 24 people (30\%). Most of them did not do as many as 56 people $(81.2 \%)$, did as many as 15 people (18.8\%). Most people who do cleanliness in the environment are 45 people (56.2\%), 35 people (43.8\%) do not. Most of the people who do not use as many as 57 people (71.2\%), use 23 people (28.8\%). Most of it is done as much as $80(100 \%)$ Maintaining Environmental Cleanliness. Most of the village people get information by socializing as many as 80 people (100\%).

\section{DISCUSSION}

This section describes the results of research based on literature reviews and previous research results. This discussion includes the interpretation and discussion of the results, limitations and implications of the research obtained from the research conducted as follows:

\section{Identifying the Characteristics of the Community Based on the Healthy Living Community Movement.}

One of the government's efforts to control and prevent the increasing number of noncommunicable diseases is through Germas, which is a systematic and planned action. This is in accordance with Presidential Instruction No. 1 of 2017 concerning the Healthy Living Community Movement, this has a major impact on the family and the lifestyle of each head of the family. "Starting from us as women, then later developing in the family environment and spreading in the wider community. ${ }^{11}$ Therefore, every woman must become a pioneer of the Healthy Living Society Movement (GERMAS) by maintaining a healthy lifestyle in their respective family environment so that family health is maintained, family productivity increases, the environment becomes clean and costs for medical treatment are reduced. ${ }^{6}$

Based on the results of the study, it was shown that 56 people $(70 \%)$ were male, while 24 were female (30\%). This shows that the head of the family and family members tend to be dominated by men. Based on the culture of decision making in the family, it is the head of the family. The role of the head of the family takes the decision to take the right action. However, 
not all family heads are held by men, the fact is that women / wives are the backbone of the family due to the condition of their husbands who do not work either because of illness or other. ${ }^{12}$

Education level plays an important role in public health. Community education can affect people's knowledge. Education is one of the community organizing efforts to improve health because the level of education can affect the healthy behavior of a family with a less supportive level of education which will lead to low environmental awareness, the better the level of formal education so that it will mature understanding of knowledge about germas.

Based on the results of the study, it shows that the highest level of education is 29 people $(36.2 \%)$ graduated from high school and the lowest is 4 people (5\%) who did not graduate from elementary school. Based on the results of other research, it shows that education will influence a person's behavior in life patterns. ${ }^{13}$ The results of this study are supported by other research which states that most respondents with secondary education (SMA) will influence family behavior in implementing healthy living behaviors because respondents have sufficient insight. ${ }^{8}$

The pattern of healthy living behavior in riverbank communities is by regulating diet, getting enough rest, exercising regularly and eating vegetables. All of this is done regularly to maintain health in life. If the body is in a healthy condition, you can do your usual activities, namely as a farmer. The income earned will affect the economy and health welfare in the family. ${ }^{14,15}$

Work is a grouping of one's duties and responsibilities to meet needs that must be met and achieve a better standard of living. ${ }^{16}$ In addition, based on the research results according to other study, it is stated that work affects the ability of parents to provide nutrition for family members. ${ }^{17}$
It is proven in this study that the occupation of most respondents is self-employed 99 (30\%). In Indonesia, fishermen usually live in rural areas. The stability of food availability at the household level is measured based on the adequacy of food availability and the frequency of meals for household members in a day. The combination of the two as an indicator of food sufficiency produces an indicator of the stability of food availability. ${ }^{18}$ If this availability is sufficient, the family will be able to realize health and apply germas properly. ${ }^{5}$

The researcher got the income of the community in the village of Pembantanan $<$ Rp. 2,000,000; 41 people (51.2\%) while income > Rp. 2,000,000 totaling 39 (48.8\%) so that the purchasing power of the community in the village of pembatanan is still very low, both primary and secondary needs. As is the case according to the other study, which states that family income is one of the factors affecting the purchasing power of families to provide health needs. ${ }^{19}$ family. The higher the family income, the higher the pattern of family purchasing power in meeting the health needs of family members. Based on othe research As a result, most of the head of the family who played a poor role in the health of family members was a family head whose economy was low. ${ }^{20}$ Low-income families tend not to be able to meet their food needs, the diversity of foodstuffs is not guaranteed, because with limited money there are not many choices of foodstuffs to be consumed.

The pattern of healthy living behavior in riverbank communities by adjusting the diet, getting enough rest, exercising regularly eating vegetables. All of this is done regularly to maintain health in life.

The income earned will affect the economy and health welfare in the family. Based on the results of research conducted, it was found that the highest number of private workers was $30(37.5 \%)$ and the lowest was civil servants (3.8\%). Work is a grouping of 
one's duties and responsibilities to meet needs that must be met and achieve a better standard of living. Research conducted by other research states that work affects the ability of parents to provide nutrition for family members. ${ }^{18}$

The stability of food availability at the household level is measured based on the adequacy of food availability and the frequency of meals for household members in a day. The combination of the two as an indicator of food sufficiency produces an indicator of the stability of food availability. If this availability is sufficient, the family will be able to realize health. ${ }^{21}$

The research that was obtained based on people's knowledge about the GERMAS program was 53 people $(66.2 \%)$ and 27 people (33.8\%) did not know. The low number obtained by researchers is a basic reference and is not in line with other study, namely the main objective in providing health education, namely changing a person's knowledge, attitudes and behavior while Knowledge is the result of "knowing", and this occurs after people do sensing of a particular object. Knowledge or cognitive is a very important domain for the formation of one's actions (overt behavior). ${ }^{16}$

The research that was done got physical activity that did as many as $70(87.5 \%)$ and those who did not do 10 people (12.5\%). Based on research by other research on the relationship of physical activity, it shows that there are several things that can affect activity, including age, gender, occupation, education. ${ }^{22}$ Meanwhile, research according to other study on the relationship of physical activity shows that people with good physical activity are less at risk of contracting non-communicable events than people who have less physical activity. ${ }^{23}$

Adequate consumption of vegetables and fruits plays a role in maintaining normal blood pressure, blood sugar and cholesterol levels. Adequate consumption of vegetables and fruits will reduce the risk of having difficulty defecating (defecating / constipation) and obesity. This shows that adequate consumption of vegetables and fruits plays a role in preventing chronic non-communicable diseases. The Healthy Living Society Movement (Germas) invites people to consume 2-3 servings of vegetables and fruit every day, especially local vegetables and fruits, which are sufficient to consume vegetables and fruits. The fiber content in 100 grams of watermelon is 0.5 grams, oranges 0.1 grams, bananas 0.63 grams, salak is 0.5 grams and apples 0.65 grams. The fiber content of the vegetables consumed by respondents was 2.6 grams of cassava leaves, 1.1 grams of carrots, 0.7 grams of chayote, 0.2 grams of mustard greens and 1 g of kale. ${ }^{24}$

In accordance with the theory that hypertension is the majority of women and the risk factors for a family history of hypertension are 197 people (58.3\%). The age factor is very influential on hypertension because with increasing age, the higher the risk of hypertension. This is often caused by natural changes in the body that affect the heart, blood vessels and hormones. Based on the results of the research conducted in the assistance village, data were obtained for as many as 73 smokers (91.2\%) and 7 non-smokers (8.8\%). Actually information about the dangers of smoking has often been socialized by the government through the Ministry of Health. The Ministry of Health also has a community movement program (Germas), which is a healthy life without smoking with modules that are easily accessible on the internet, and information accompanied by pictures that are interesting to read. ${ }^{25}$ However, programs like this need to be intensified again in order to reduce the prevalence of teenage smoking in Indonesia. The results showed a number of respondents (57.3\%) had knowledge that the subject affected by the dangers of smoking was only for people around smokers. This shows that there are still many smokers in the village and this 
does not stop the negative effects of smoking.

The results of the study found that the behavior of consuming alcohol in the village community was very high. Out of 80 samples, $56(70 \%)$ consumed and 24 (30\%) did not consume alcohol. Research conducted by other research found that alcohol consumption is influenced by factors of lack of self-confidence, curiosity or trying, flight from problems, lack of knowledge, bad family, bad environment significantly increases alcohol addiction (addiction). ${ }^{26}$

The rampant circulation of alcohol causes people to freely buy it. Alcohol is known to be intoxicating and makes you unconscious and some even lead to death. Currently, various types of mixed liquor are also circulating in the market that mix various types of alcoholic drinks with harmful ingredients such as mosquito repellent creams. The risks faced can clearly lead to death. The school and related agencies must be aware of this and should follow the development of various information so that it can be disseminated to school students.

Health checks in the assisting village community who carried out as many as 15 people (18.8\%) and those who did not do 65 people $(81 . \% 2)$, according to the researchers there was a very lack of public awareness of the importance of awareness in terms of conducting regular health checks. The average reason why respondents do not carry out routine health checks is because they are afraid of the results of the examination or know about their health problems, and are considered to be activities that waste money because they are carried out when the person is in a state that looks fit. ${ }^{27}$ The quality of education also affects their awareness to carry out routine health checks. In contrast to the results of other research regarding the educational results of respondents having routine health checks, it shows that $72 \%$ of respondents who routinely carry out health checks are college graduates. In addition, the higher a person's economic capacity, the more routine that person will take medical tests. Business at work also affects a person in routine health checks, besides that the time for health checks at health service places is during working hours.

The environment is an external variable that affects policy implementation. The environment in implementing the GERMAS policy includes socio-economic conditions and community technology. Most of the informants agreed that the socio-economy of society had an effect on policy implementation, especially in terms of behavior. Increasing the willingness, awareness and ability of the community to have a healthy lifestyle is the goal of GERMAS. Research from Yuliandari and Herya states that families or communities with low socioeconomic status have five times greater opportunities for not behaving in a clean and healthy life than families / communities with high socioeconomic conditions. ${ }^{27}$

Based on the results of the study, it was shown that the environmental hygiene behavior in the community in the Assistance Village was carried out by $45(56.2 \%)$ and not done by 35 (43.8\%). This is in line with research conducted by Iskandar (2018) which found that environmental cleanliness is carried out by all residents together with full awareness so as to produce a clean and healthy environment.

The results of the study found that the behavior of using healthy latrines in the community in the village of assistance 23 (28.8\%) used latrines and 57 (71.2\%) still did not use latrines. People still lack awareness of the importance of latrines in terms of the requirements for a healthy home, namely the availability of clean and proper latrines and the availability of clean water at home. Other research found that there is a relationship between ownership 
of a healthy latrine with education, knowledge, attitudes, and family income.

The results of the study found that the media provided information related to the GERMAS program with a total of $80(100 \%)$. Overall, this indicates that the village community in the village of Pembantanan used the media as a means of obtaining information in the health sector. This research is in line with research conducted by other study which found that the cultivation of clean and healthy living or healthy living habits has an impact on: 1). Increased knowledge about the importance of maintaining health through the healthy life community movement (GERMAS), 2). Increase public awareness about the importance of health and PHBS, 3). The community can apply PHBS directly in their daily life. ${ }^{27,28}$

Information in the implementation of the GERMAS policy includes transmission, clarity and consistency. Transmission is the process of delivering policy information to both implementers and groups. Information on GERMAS is carried out using media such as printed media (leaflets, posters, stickers, billboards, brochures and others), electronic media (radio and television), and social media (Twitter, Instagram, Facebook, Youtube and Whatsapp). Apart from these media, GERMAS socialization was provided through meetings / meetings, posyandu activities, posbindu activities and other health education activities. The submission of information that has been carried out has not been received thoroughly, this is because there are still schools that have never received socialization from the Health Office. ${ }^{29}$

The transmission process in the communication of media information affects the clarity of policy implementation. Clarity of communication can be assessed how the implementers and target groups know the intent, content and objectives of the policy itself. The results of the interviews that have been carried out, the delivery of GERMAS information carried out by the Health Office and Puskesmas has been carried out clearly in accordance with the objectives and indicators of GERMAS. 23,30

Based on the results of interviews conducted by researchers, the community has been given socialization related to GERMAS in accordance with the indicators. In addition, the delivery of GERMAS is provided by integrating it into existing programs / activities. This is because each of the GERMAS indicators already has its own program / activity, while the GERMAS socialization in particular is only carried out at certain times and the schedule for each puskesmas to hold it varies.

A public figure according to the Law of the Republic of Indonesia Number 8 of 1987 is "a person who because of his social position receives honor from the community and / or the government" (Government of the Republic of Indonesia, 1987). The position of public figures is obtained by individuals because of their knowledge, wisdom and wisdom, and their success in living life in society. The wisdom and knowledge possessed by community leaders usually become role models for people who are in their respective fields. Because of their activities, skills and characteristics, community leaders are people who are respected and respected.

Based on the results of the study, it was found that social activities and community leaders got a score of $80(100 \%)$ that played a role as community leaders, among others, as a social controller, guardian and enforcer of values and norms that apply in society. In addition, community leaders also play a role in solving various problems that occur. Community leaders have an obligation to provide support, guidance, motivation and direction to the community. Community leaders also act as support providers. Support from community leaders can be divided into emotional support, reward support, instrumental support and 
informative support. Emotional support is indicated by expressions of empathy, care and concern. Appreciative support is indicated by expressions of respect and encouragement to move forward. Instrumental support is indicated by providing direct assistance according to community needs. Informative support is indicated by providing advice, hints, suggestions and feedback.

\section{Implementation of GERMAS Program Activities}

Germas or Healthy Living Community Movement is a movement launched to achieve SPM and PIS PK. So that it is in line with Germas's goal of realizing a better degree of public health. As an effort to increase awareness, willingness, and ability to behave in a healthy society, Presidential Instruction Number 1 of 2017 concerning the Healthy Living Community Movement (Germas) has been issued. ${ }^{25}$

The current health problem in the assisting village faces a major challenge, namely the triple burden of disease, because there are still infectious diseases, an increase in noncommunicable diseases and diseases that should have been resolved do not reappear. Non-communicable diseases such as hypertension, stroke, heart disease and diabetes are in the highest rank.

The morbidity and mortality rates as well as the demand for health services (treatment) are expected to continue to increase. This is driven by changes in the lifestyle of people who tend to be physically inactive (for example spending a lot of time watching TV), low consumption of fruits and vegetables (eating lots of processed, readyto-eat food, high in sugar, salt, etc.), lack of concern for check or detect early disease. ${ }^{31}$ Public health status is influenced by behavior, environment, health services, and heredity. Behavior and the environment play a role for more than $73 \%$ of the health status of the community and a number of risk factors for health behavior that occur, namely the population lack of physical activity (70\%), less consumption of fruits and vegetables (75\%). As is known at this time, poor diet, unbalanced nutritional intake, lack of physical activity, lack of concern in routine health checks, have been inherent in most of the people's daily lives. This actually needs to be watched out for because the worst events that can be lifethreatening are generally triggered by these bad behaviors. The Ministry of Health develops a Healthy Indonesia program, Healthy Living Community Movement through a family approach. ${ }^{32}$

Germas is a national movement that cannot only rely on the role of the health sector alone. The role of ministries and institutions in other sectors also determines and is supported by the participation of the community in practicing a healthy lifestyle. The socialization of Germas is expected to be able to invite people to cultivate a healthy life, in order to be able to change unhealthy habits or behavior. Based on the results of the study, the results showed that questionnaires were distributed to 80 respondents who were randomly taken from 12 RTs in the assistance village area. This data can be seen from 10 indicators, there are 4 indicators that have not been implemented properly in the community in implementing the germas program.

The main activities carried out within the framework of Germas are: increasing physical activity, enhancing Clean and Healthy Living Behavior (PHBS), providing healthy food and accelerating nutrition improvement, increasing prevention and early detection of disease, improving environmental quality, increasing healthy living education. The results showed the application of the Healthy Community Movement (GERMAS) in the Village Assistance, Banjar Regency. It can be seen that respondents can carry out activities, consume fruits and vegetables and prevent disease by adopting a healthy and regular lifestyle. 
Most of the respondents still use the latrine a lot as much as $57 \%$ while the community hygiene pattern in cleaning the house is $45 \%$, and the lack of awareness in carrying out health checks is $65 \%$ and the smoking behavior pattern is $73 \%$. This is in line with the GERMAS program organized by the Ministry of Health that in order to improve the quality of life, GERMAS invites the public to cultivate a healthy life, in order to be able to change unhealthy habits or behavior.

The implementation of GERMAS must start from the family, because the family is the smallest part of society that shapes personality. Based on the results of research on Basic Health Research, it was stated that many respondents did not carry out routine health checks, including checking blood pressure, blood sugar, weighing, measuring abdominal circumference, checking cholesterol. ${ }^{33}$ From several research results, it is stated that there is a lack of understanding related to government programs, namely Germas, one of the reasons for not understanding health problems.

\section{Implementation of GERMAS Program Activities using the Penta Helik approach}

The bureaucratic structure in implementing the GERMAS policy includes Standard Operating Procedures (SOP) and division of tasks (fragmentation). The regulations that have been used as SOP guidelines in implementing GERMAS implemented by the Health Office and BAPPEDA are Presidential Instruction Number 1 of 2017 and Central Java Governor Regulation Number 35 of 2017. Furthermore, there is a follow-up from the Regional Secretary by issuing Circular Number 440/6192 dated 7. November 2018 aimed at regional apparatus organizations (OPD) to play an active role in GERMAS.

Based on the results of the study, it was found that there were no regional regulations and RAD on GERMAS in the Assistance Village. Regional regulations are deemed necessary not just implementing regulations from higher legislation, but can become a forum for community aspirations, as well as being able to absorb and accommodate the special conditions of a region. ${ }^{5}$

The basis of the SOP because RAD can be used as a guide for each OPD to prepare GERMAS activities, as well as a guide in monitoring the evaluation of the implementation of GERMAS activities. SOPs have an influence on policy implementation. SOPs are used in harmonizing actions for policy implementers in a complex and widespread organizational structure, which can lead to flexibility and equality in implementing regulations. SOPs that are flexible are more adaptable to responsibilities compared to rigid SOPs. ${ }^{11}$

Fragmentation relates to the distribution of responsibilities and the division of tasks to those who implement policies. Based on the results of interviews with informants, it was stated that the implementation of GERMAS was coordinated by the Health Office. The division of tasks between organizations or implementing agencies requires coordination. According to Winarno, the greater the coordination needed, the less likely the success of the policy will be. ${ }^{11}$ This is in accordance with other research which states that the division of tasks and coordination between overlapping implementers will cause the implementation process to be less effective. ${ }^{6}$

\section{CONCLUSION}

Characteristics of respondents based on the results of the description of the community movement to live a healthy life, most of the respondents did physical activity, consumed fruits and vegetables, did not have regular health checks, did not carry out community movement activities to live well. Community suggestions are expected to implement a healthy living community movement which includes the results of this 
research. Hopefully, the people of Assistance Village will implement a healthy living community movement which includes 4 indicators, namely increasing knowledge, not drinking alcohol, environmental cleanliness, and not using latrines, so that health problems are not contagious.

The community is expected to implement a healthy living community movement which includes 4 indicators, namely indicators, namely increasing knowledge, smoking behavior, environmental hygiene, and not using latrines, so as to avoid health problems from non-communicable diseases.

\section{ACKNOWLEDGMENTS}

The researcher would like to say thank you to all respondents who participated in this research.

\section{CONFLICTS OF INTEREST}

Neither of the authors has any conflicts of interest that would bias the findings presented here.

\section{REFERENCES}

1. Notoatmodjo S. Promosi Kesehatan: Teori Dan Aplikasi. PT Rineka Cipta; 2010.

2. Kemenkes RI. Profil Kesehatan Indonesia. In: Depkes RI; 2018.

3. Banjar D. Profil Kesehatan Kota Banjar Tahun 2018.; 2016.

4. Zainul J, Nasrul M. Inisiasi Gerakan Masyarakat Sehat (Germas) Di Poltekkes Kemenkes Palu. Poltekita J Ilmu Kesehat. 2019;13(1):54-61.

5. Suryani D, Nurdjanah EP, Yogatama Y, Jumadil M. Membudayakan Hidup Sehat melalui Gerakan Masyarakat Hidup Sehat (Germas) di Dusun Mendang III, Jambu, Dan Jrakah Kecamatan, Tanjungsari, Gunungkidul. J Pemberdaya Publ Has Pengabdi Kpd Masy. 2019;2(1):65.

6. Noor N. Studi Implementasi Germas Pada Penderita Hipertensi Di Puskesmas Tapin Utara Tahun 2020. Universitas Islam Kalimantan MAB; 2020.
7. Junita E, Handayani Y, Alfiah LN. GERMAS (Gerakan Masyarakat Hidup Sehat) Di Desa Rambah Hilir. Kumawula J Pengabdi Kpd Masy. 2020;3(1):100-105.

8. Rahmawaty E, Handayani S, Sari MHN, Rahmawati I. Sosialisasi dan harmonisasi gerakan masyarakat hidup sehat (germas) dan program indonesia sehat dengan pendekatan keluarga (pis-pk) di Kota Sukabumi. LINK. 2019;15(1):27-31.

9. Kementerian Kesehatan Republik Indonesia. Pedoman Umum Program Indonesia Sehat Dengan Pendekatan Keluarga. Kementerian Kesehatan RI; 2016. http://library1.nida.ac.th/termpaper6/sd/255 4/19755.pdf

10. Habibie WL. Health Reform in Indonesia towards Sustainable Development Growth (Case Study on BPJS Kesehatan, Health Insurance in Indonesia). Rev Integr Bus Econ Res. 2017;6(3). Accessed November 16, 2018. http://buscompress.com/journal-home.html

11. Winarno B. Kebijakan Publik Era Globalisasi. Yogyakarta CAPS. Published online 2016.

12. Retnowulandari W. Kepala Keluarga dalam Hukum Keluarga di Indonesia: Tinjauan Perspektif Gender dalam Hukum Agama, Adat, dan Hukum Nasional. J Huk PRIORIS. 2017;5(3):235-245.

13. Angela M, Sianturi SR, Supardi S. Hubungan antara Pengetahuan, Sikap dan Perilaku Pencegahan HIV/AIDS pada Siswa SMPN 251 Jakarta. J Penelit dan Pengemb Pelayanan Kesehat. 2019;3(2):67-72.

14. Aida PM. Analisis Pelaksanaan Gerakan Masyarakat Hidup Sehat Di Wilayah Kerja Puskesmas Susoh Kabupaten Aceh Barat Daya Tahun 2019. Published online 2020.

15. Notoatmodjo S. Pendidikan dan Perilaku Kesehatan, Cetakan 2. PT Rineka Cipta Jakarta. Published online 2007.

16. Notoatmodjo Soekidjo. Promosi Kesehatan Dan Prilaku Kesehatan Edisi Revisi 2012. Rineka Cipta; 2012.

17. HDJ M. Promosi Kesehatan. 5th ed. EGC; 2009.

18. Rosyadi DW. Hubungan Antara Pengetahuan Ibu Bekerja, Jam Kerja Ibu dan Dukungan Tempat Bekerja dengan Keberhasilan Pemberian ASI Eksklusif di Wilayah Kerja Puskesmas Banyudono I. J Univ muhammadiyah Surakarta. Published online 2016.

19. Taylor C. Fundamentals of Nursing: The Art and Science of Nursing Care. 7th ed. Wolters Kluwer Health/Lippincott Williams \& Wilkins; 2011.

20. Nugroho K, Sanubari T, Rumondor J. Faktor 
risiko penyebab kejadian. J Kesehat Kusuma Husada - Januari 2019. Published online 2019:32-42.

21. Spronk I, Kullen C, Burdon C, O'Connor H. Relationship between nutrition knowledge and dietary intake. Br J Nutr. 2014;111(10):17131726. doi:10.1017/S0007114514000087

22. Mila M, Anida A, Ernawati Y. Hubungan Aktifitas Fisik Dengan Tekanan Darah Pada Lansia Di Dusun Miri Desa Sriharjo Imogiri Bantul Yogyakarta. J Kesehat Masy. 2017;10(1).

23. Nurfitriani N, Anggraini E. Pengaruh Pengetahuan dan Motivasi Ibu Rumah Tangga Tentang Gerakan Masyarakat Hidup Sehat (GERMAS) di Kelurahan Talang Bakung Kota Jambi. J Ilm Univ Batanghari Jambi. 2019;19(3):532-538.

24. Graham DJ, Laska MN. Nutrition Label Use Partially Mediates the Relationship between Attitude toward Healthy Eating and Overall Dietary Quality among College Students. J Acad Nutr Diet. 2012;112(3):414-418. doi:10.1016/j.jada.2011.08.047

25. Kementerian Kesehatan Republik Indonesia. Pedoman Umum Program Indonesia Sehat Dengan Pendekatan Keluarga.; 2016.

26. Enander J, Ivanov VZ, Mataix-Cols D, et al. Prevalence and heritability of body dysmorphic symptoms in adolescents and young adults: A population-based nationwide twin study. Psychol Med. 2018;48(16):2740-2747. doi:10.1017/S0033291718000375
27. Yuliandari DW, UI NH. Pengaruh Pengetahuan Dan Sosial Ekonomi Keluarga Terhadap Penerapan Perilaku Hidup Bersih Dan Sehat (Phbs) Tatanan Rumah Tangga Di Wilayah Kerja Puskesmas X Kota Kediri. J Wiyata Penelit Sains dan Kesehat. 2017;3(1):17-22.

28. Trisnowati H, Daduk SS. Hubungan pengetahuan dan sikap terhadap phbs di rumah tangga dengan perilaku merokok dalam rumah kepala rumah tangga di Dusun Karangnongko Yogyakarta. Med Respati J Ilm Kesehat. 2017;12(4):1-11.

29. Printina AB. Pengaruh Promosi Kesehatan Melalui Video Vlog Terhadap Tingkat Pengetahuan Tentang Penyalahgunaan Narkoba Pada Siswa Siswi Di Smp Strada Marga Mulia Jakarta Selatan. J Ris Kesehat Nas. 2018;2(1):59. doi:10.37294/jrkn.v2i1.89

30. Adha AY, Wulandari DR, Himawan AB. Perbedaan Efektivitas Pemberian Penyuluhan Dengan Video Dan Simulasi Terhadap Tingkat Pengetahuan Pencegahan Tb Paru (Studi kasus di MA Husnul Khatimah Kelurahan Rowosari Kecamatan Tembalang Kota Semarang). J Kedokt Diponegoro. 2016;5(4).

31. Dedi K. Aksi Bersama Melakukan GerakanMasyarakat Hidup Sehat. Kemenkes, RI Ed. 2017;1:2017.

32. Heryati GS. Faktor-Faktor Yang Berhubungan Dengan Kepatuhan Diet Diabetes Mellitus Pada Pasien DM. J Keperawatan. 2014;1(3):97-107.

33. RI K. Laporan Riskesdas 2013. 